\title{
Serum Albumin/Globulin ratio in Tuberculosis and HIV Patients any Relationship?
}

\author{
Shingdang $\mathrm{J}^{1}$, Bot $\mathrm{Y}^{1}$, Ojo $\mathrm{O}^{1}$, Edeh $\mathrm{O}^{1}$, Essien $\mathrm{C}^{1}$, Bwende $\mathrm{E}^{2}$, Okolie $\mathrm{C}^{2}$ and Ekwempu $\mathrm{Al}^{1^{\star}}$ \\ ${ }^{1}$ Department of Medical Laboratory Sciences, Faculty of Medical Sciences, University of Jos, Plateau State, Nigeria \\ ${ }^{2}$ Department of Microbiology, Landmark University, Kwara State, Nigeria
}

"Corresponding author: Ekwempu Al, Department of Medical Laboratory Sciences, Faculty of Medical Sciences, University of Jos,Plateau State, Nigeria, Tel: 0805263354; E-mail: adaekwem@yahoo.com

Received date: January 31, 2016; Accepted date: March 5, 2016; Published date: March 15, 2016

Copyright: (c) 2016, Shingdang J, et al. This is an open-access article distributed under the terms of the Creative Commons Attribution License, which permits unrestricted use, distribution, and reproduction in any medium, provided the original author and source are credited.

\section{Abstract}

Background: Tuberculosis (TB) remains an important communicable disease all over the world. The serum protein levels in TB patients may be altered by low immunity, edema and decrease antioxidant activity. This study therefore evaluates the relationship between TB and serum proteins with emphasis on albumin/globulin ratio an important component for treatment and management of TB. The study also aimed at comparing albumin/globulin ratio of tuberculosis patients, HIV patients, those on drugs and naive patients.
\end{abstract}

Materials and Method: A total of 120 participants (42 control and 78 patients) aged between 15 years-65 years and sex-matched attending Plateau State Specialist Hospital were enrolled. Total protein was estimated using Biuret method and albumin by Bromocresol green method, serum globulin value was obtained by subtracting albumin from total protein then albumin/globulin ratio was calculated. Screening for HIV antibody was done using Determine strip and confirmed with Unigold.

Results: Evaluated albumin/globulin ratio (1:4) was obtained in the TB case when compared to control group $(p=$ $0.002)$. The albumin was significantly higher in study group compared to control $(2.95 \pm 0.86$ and $2.75 \pm 0.65 \mathrm{~g} / \mathrm{dl})$ while total protein and globulin was significantly lower $(6.17 \pm 1.66$ and $6.76 \pm 0.86 \mathrm{~g} / \mathrm{dl}, \mathrm{p}=0.011$ and $3.22 \pm 1.9$ and $3.97 \pm 0.86 \mathrm{~g} / \mathrm{dl}$ with $\mathrm{p}=0.016$. Patients seropositive for HIV antibody had a decrease in serum total protein, albumin and globulin but high albumin/globulin ratio. Total protein, albumin, globulin and albumin/globulin of TB patients not on drugs were elevated compared to those currently undergoing treatment. Age group $<30$ years when compared with age group between $30-40$ years showed significant low albumin and albumin/globulin ratio (2.74 \pm 0.75 and $3.10 \pm 0.72 \mathrm{~g} / \mathrm{dl}, \mathrm{p}=0.025$ and $0.97: 1 \pm 0.66$ and $1.42: 1 \pm 1.47, \mathrm{p}=0.042$ ).

Conclusion: Our work suggests that individuals < 30 years had hypoproteinaemia which maybe lead to low immunity. Our results also suggests that albumin/globulin ratio of TB patients on drugs were higher which may be due to hyperalbunaemia observed in this group. For effective treatment and management of TB infected individuals, appropriate use of drugs, adherence to treatment plan, close monitoring of dietary intake is needful in building and improving immunity.

Keywords: Tuberculosis; HIV; Albumin total protein; Globulin

\section{Introduction}

Tuberculosis (TB) is a common and often deadly infectious disease caused by various strains of mycobacterium usually Mycobacterium Tuberculosis in humans [1]. It was originally referred to as Koch's bacillus after Robert Koch who first identified it in 1882 in Berlin, Germany [2]. Mycobacterium tuberculosis is found in infected human and is transmitted to primates, dogs and other animals that are in close association with man. M. bovis is the causative agent of tuberculosis in cattle and is transmitted to man, primates, pigs and domestic animals [2]. TB usually attacks the lungs but can affect other parts of the body such as the lymph nodes, kidneys, bones, central nervous system, peritoneum, eye as well as the skin and spread through air when people who have the disease sneeze or spit [3]. When people with active pulmonary TB cough, sneeze, speak, sing, or spit, they expel infectious aerosol droplets 0.5 to $5.0 \mu \mathrm{m}$ in diameter. A single sneeze can release up to 40,000 droplets [4]. Each one of these droplets may transmit the disease, since the infectious dose of tuberculosis is very low (the inhalation of fewer than 10 bacteria may cause an infection) [5].

People with prolonged, frequent, or close contact with people with TB are at particularly high risk of becoming infected, with an estimated $22 \%$ infection rate [6].

WHO estimates that 210,000 new cases of all forms of tuberculosis occurred in Nigeria in 2010 and more than $90 \%$ of new cases and deaths occurred in developing countries [7]. There are changes in levels of serum proteins in response to both acute and chronic infections. In air infection like Mycobacterium Tuberculosis, it is expected that changes in plasma protein levels will occur in patients. However, the change in level of each protein at any particular time usually reflects the net effect of the rate of synthesis and rate of catabolism as a result of host microbe interaction. In chronic infectious TB disease, the albumin shows a decrease while globulin content shows 
an increase leading to low Albumin to Globulin (A/G) ratio and albumin to alpha-2 globulin ratios [8].

Plasma protein fractions are albumin, globulin and fibrinogen. Albumin is a small globular protein with molecular mass of $66.3 \mathrm{kDa}$. It is the most abundant protein, has no carbohydrate side chain but is highly soluble in water due to high negative charge at $\mathrm{p}^{\mathrm{H}}$ 7.4. Albumins are synthesized by hepatic parenchyma cells. It functions mainly for maintaining colloidal osmotic pressure and also serves for transportation of large compounds such as free fatty acids, amino acids and drug [9].

Serum protein consists of albumin and globulins and its level in normal subjects vary from $6-8 \mathrm{~g} / \mathrm{dl}$. Normal range of albumin is 3.2-4.5 $\mathrm{g} / \mathrm{dl}$ and globulin ranges from 2.3-3.5 g/dl [2]. Tuberculosis is one of the principal infectious causes of disease and death worldwide, yet there are very marked differences in the incidences from region to region roughly, one-third of the world's population has been infected with Mycobacterium tuberculosis, and new infections occur at a rate of one per second on a global scale (WHO, 2010). However, most infections with $\mathrm{M}$. tuberculosis do not cause TB disease, [10] and 90-95\% of infections remain asymptomatic [11].

In 2007, an estimated 13.7 million people have active tuberculosis disease with 9.3 million new cases and 1.8 million deaths, while in 2010, there were an estimated 8.8 million new cases and 1.5 million associated deaths, mostly occurring in developing countries [12]. The annual incidence rates vary from country to country. At one extreme there is an incidence of disease of less than 5 per 100,000 per annum in the population of Western Europe [13]. Intermediate incidence of 50 100 per 100,000 and 100 - 200 per 100,000 were reported in Eastern Europe and the Indian subcontinent respectively. Africa has an annual incidence rate of 363 per 100,000 populations [14].

Nigeria has the fourth highest burden of tuberculosis in the world, with an annual incidence of 311 cases per 100,000 populations in 2006 [15], although tuberculosis is so prevalent that it has been declared a global emergency most people do not develop the disease after infection. The ratio of infection to the disease is about $10 \%$. There is approximately about one third of the world population-two billion people have been infected with tubercle bacillus [16], but the great majority only has latent tuberculosis infection. In 2007, an estimated 13.7 million people had active tuberculosis disease with 9.3 million new cases and 1.8 million deaths, while in 2010, there were an estimated 8.8 million new cases and 1.5 million associated deaths, mostly occurring in developing countries [12]. The annual incidence rates vary from country to country. At one extreme there is an incidence of disease of less than 5 per 100,000 per annum in the population of Western Europe [13]. Intermediate incidence of 50 - 100 per 100,000 and 100 - 200 per 100,000 were reported in Eastern Europe and the Indian subcontinent respectively. Africa has an annual incidence rate of 363 per 100,000 populations [14].

Nigeria has the fourth highest burden of tuberculosis in the world, with an annual incidence of 311 cases per 100,000 populations in 2006, although tuberculosis is so prevalent that it has been declared a global emergency most people do not develop the disease after infection. The ratio of infection to the disease is about $10 \%$.

The incidence of TB varies with age, in Africa TB primarily affects adolescent and young adults [17]. However, in countries where TB has gone from high to low incidence, such as United States TB is mainly a disease of older people or of immunocompromised [18]
There are a number of known factors that make people more susceptible to TB infection worldwide the most important of these is HIV/AIDS compromise the immune system. WHO, reported that approximately 11 million people around the globe are infected with both HIV and TB. Smoking more than 20 cigarettes a day also increases the risk of TB by two to four times [19].

Other disease states that increase the risk of developing tuberculosis are chronic liver disease, malnutrition and alcoholism [20]. Diets may also affect the risk. For example, among immigrant in London from the Indian subcontinent, vegetarians Hindu Asians were found to have an 8.5 fold increase risk of TB, compared to Muslim who eat meat and fish daily [21]. This increased risked could be caused by micronutrient deficiencies, possibly irons, Vitamin B12 or Vitamin D and an increased risk of contracting tuberculosis [22].

Also overcrowding may contribute to the spread of disease. Prisoners especially in poor countries are particularly vulnerable to infections such as HIV/AIDS and TB. TB out breaks have been reported in prisons is much higher than among the general population in some countries as much as 40 times higher due to overcrowding [23].

This work was therefore aimed at estimating albumin/globulin ratio in serum of tuberculosis patients, comparing the albumin/globulin ratio in tuberculosis patients on drugs, those not on drugs and determining the relationship between $\mathrm{A} / \mathrm{G}$ ratio and $\mathrm{TB}$ disease.

\section{Material and Method}

The study was conducted on out patients in Plateau Specialist Hospital Jos, a total of 120 blood samples from subjects between the ages of 15 years - 65 years were analysed. 78 were from patients with confirmed pulmonary tuberculosis i.e. those on anti-tuberculosis drug treatment and those not on any anti-tuberculosis drug treatment while 42 were non tuberculosis individuals who served as control participants out of the 78 patients, 64 were on TB treatment while remaining 14 were not on any form of TB treatment.

$2 \mathrm{ml}$ of blood were collected using sterile syringes with minimum stasis by venepuncture and transferred into chemically cleaned, dried and labelled sample containers. The samples were also allowed to clot, then retracted and centrifuged at 3,000 rpm for 5 minutes. The serum was then transferred to clean and well label vials for further analysis. An inclusion criterion was based on patient age i.e. between $15-60$ years and patients diagnosed for TB by using the revised National Tuberculosis Control Algorithm [24].

The Biuret test is a chemical test used for detecting the presence of peptide bonds. In the presence of peptides, a copper(II) ion forms violet-colored coordination complexes in an alkaline solution [25]. Several variants on the test have been developed, such as the BCA test and the modified Lowry test. The Biuret reaction was used to assess the concentration of proteins.

Serum Albumin was determined using the bromocresol green method based on the reaction of albumin with the dye bromocresol green to produce a coloured complex which was measured calorimetrically to give the concentration of the albumin [26].

Globulin concentration was obtained by subtracting values of total serum protein from that of serum albumin. The normal reference value being 2.3-3.5 g/dl. 
Page 3 of 6

The value for Globulin/Albumin ratio was obtained by dividing albumin value by globulin value. Normal reference value 1.2:1 - 2:1.

\section{Results}

The demographic characteristics of the study participants are shown as comprising a total of 120 participants (42 in the control group and 78 in the Tuberculosis (TB) group). The control group consisted of 27 (64.3\%) males and 15 (35.7\%) females while the TB group consisted of 46 (59\%) males and 32 (41\%) females. They were grouped based on their ages as $<30,30-40$ and $>40$ years. In the control group, 26 $(61.9 \%)$ were $<30$ years, $9(21.4 \%)$ between 30 -40years and $7(16.7 \%)$ were $>40$ years; while the TB group were 31 (39.74\%), $27(34.62 \%)$ and $20(25.64 \%)$ with the age group as $<30,30-40$ and $>40$ respectively. The mean standard deviation based on age in the control and TB groups were $30.71 \pm 10.43$ and $34.05 \pm 11.85$ respectively and $p$ value 0.115 as shown in Table 1. A total of $15(19.2 \%)$ from TB patients were reactive while $63(80.8 \%)$ were non- reactive to HIV antibody. 14 (17.9\%) were newly diagnosed subjects while $64(82.1 \%)$ were patients with prior confirmed diagnosis of TB and 35 (44.9\%) of the patients were in the continuation phase of anti-TB drugs cocktail and 29 (37.2\%) were on intensive phase anti-TB drugs whereas 14 (17.9\%) were not on any anti-TB drug treatment as shown in Table 2 . The control and TB groups had total protein, albumin, globulin and albumin/globulin ratio of $6.76 \pm 0.87$ and $6.17 \pm 1.66 \mathrm{~g} / \mathrm{dl}, 2.75 \pm 0.65$ and 2.95. $\pm 0.86 \mathrm{~g} / \mathrm{dl}, 3.97 \pm 0.86$ and $3.22 \pm 1.9 \mathrm{~g} / \mathrm{dl}$ and 0.74:1 and $1.4: 1$ $\mathrm{g} / \mathrm{dl}$ showing $\mathrm{p}$ values $0.011,0.149,0.016$ and 0.002 respectively. The mean standard deviation of total protein, albumin, globulin and albumin/globulin ratio of males in the control group compared with TB group were $6.641 \pm 0.903$ and $6.361 \pm 1.763 \mathrm{~g} / \mathrm{dl}, 2.615 \pm 0.656$ and $3.041 \pm 0.761 \mathrm{~g} / \mathrm{dl}, 3.959 \pm 0.858$ and $3.320 \pm 1.898 \mathrm{~g} / \mathrm{dl}, 0.704: 1 \pm$ 0.268 and $1.344: 1 \pm 1.142 \mathrm{~g} / \mathrm{dl}$ showing $\mathrm{p}$ values $0.374,0.014,0.103$ and 0.006 respectively as shown in Table 3 . The mean comparison of serum protein of females in the control group with that of TB group in relation to total protein, albumin, globulin and albumin/globulin ratio were $6.980 \pm 0.792$ and $5.888 \pm 1.485 \mathrm{~g} / \mathrm{dl}, 2.987 \pm 0.582$ and $2.822 \pm$ $0.994 \mathrm{~g} / \mathrm{dl}, 3.993 \pm 0.887$ and $3.066 \pm 1.916 \mathrm{~g} / \mathrm{dl}$ and $0.793: 1 \pm 0.279$ and $1.48: 1 \pm 1.582 \mathrm{~g} / \mathrm{dl}$ with $\mathrm{p}$ values of $0.002,0.480,0.028$ and 0.023 respectively.

\begin{tabular}{|c|c|c|}
\hline Variable & $\begin{array}{c}\text { Control group N } \\
(\%)\end{array}$ & TB group $\mathbf{N}(\%)$ \\
\hline Total number & 42 & 78 \\
\hline \multicolumn{3}{|c|}{ Sex } \\
\hline Male & $27(64.3)$ & $46(59)$ \\
\hline Female & $15(35.7)$ & $32(41)$ \\
\hline \multicolumn{3}{|c|}{ Age groups (in years) } \\
\hline$<30$ & $26(61.9)$ & $31(39.74)$ \\
\hline $30-40$ & $9(21.4)$ & $27(34.62)$ \\
\hline$>40$ & $7(16.7)$ & $20(25.64)$ \\
\hline \multirow[t]{2}{*}{ Mean } & $30.71 \pm 10.43$ & $34.05 \pm 11.85$ \\
\hline & 0.115 & \\
\hline
\end{tabular}

Table 1: Demographic characteristics of the study participants.

\begin{tabular}{|c|l|l|}
\hline Variable & Frequency & Percentage \\
\hline HIV status & & \\
\hline Reactive & 15 & 19.2 \\
\hline Non- reactive & 63 & 80.8 \\
\hline Total TB Diagnosis & 78 & 100 \\
\hline New & 14 & 17.9 \\
\hline Confirmed & 64 & 82.1 \\
\hline Total & 78 & 100 \\
\hline Treatment phase & & \\
\hline Intensive & 29 & 37.2 \\
\hline Continuation & 35 & 44.9 \\
\hline Not yet on treatment & 14 & 17.9 \\
\hline Total & 78 & 100 \\
\hline
\end{tabular}

Table 2: Characteristics of the TB study participants.

The TB subjects who were positive for HIV antibody had total protein, albumin, globulin and albumin/globulin ratio values as $6.11 \pm$ $1.64 \mathrm{~g} / \mathrm{dl}, 2.67 \pm 0.96 \mathrm{~g} / \mathrm{dl}, 3.44 \pm 2.29 \mathrm{~g} / \mathrm{dl}$ and1.52:1 $\pm 1.89 \mathrm{~g} / \mathrm{dl}$ respectively while those negative for HIV antibody had $6.18 \pm 1.68$ $\mathrm{g} / \mathrm{dl}, 3.01 \pm 0.84 \mathrm{~g} / \mathrm{dl}, 3.16 \pm 1.81 \mathrm{~g} / \mathrm{dl}$ and $1.37: 1 \pm 1.18 \mathrm{~g} / \mathrm{dl}$ respectively with $\mathrm{p}$ values of $0.89,0.2116,0.666$ and 0.78 .

The mean and standard deviation values of newly diagnosed and those on treatment (old) they were shown to have $6.60 \pm 1.37$ and 6.07 $\pm 1.71 \mathrm{~g} / \mathrm{dl}, 3.32 \pm 1.11$ and $2.87 \pm 0.79 \mathrm{~g} / \mathrm{dl}, 3.28 \pm 1.90$ and $3.20 \pm 1.91$ $\mathrm{g} / \mathrm{dl}$ and 1.69:1 \pm 1.98 and $1.34: 1 \pm 1.15 \mathrm{~g} / \mathrm{dl}$ for total protein, albumin, and globulin and albumin/globulin ratio respectively. $\mathrm{P}$ values obtained were $0.226,0.077,0.892$ and 0.366 respectively while mean \pm standard deviation of total protein, albumin, globulin and albumin/ globulin ratio of test group based on intensive and continuation phase of treatment were $6.20 \pm 1.46$ and $5.97 \pm 1.91 \mathrm{~g} / \mathrm{dl}, 2.84 \pm 0.99$ and 2.89 $\pm 0.59 \mathrm{~g} / \mathrm{dl}, 3.36 \pm 1.80$ and $3.07 \pm 2.01 \mathrm{~g} / \mathrm{dl}$ and $1.25: 1 \pm 1.19$ and $1.40: 1 \pm 1.14 \mathrm{~g} / \mathrm{dl}$ respectively with their $\mathrm{p}$ values as $0.591,0.792,0.559$ and 0.612 as shown in Table 4 .

The mean \pm standard deviation for total proteins, albumin, globulin and albumin/globulin ratio for enrolled group less than 30 years were $6.32 \pm 1.24 \mathrm{~g} / \mathrm{dl}, 2.74 \pm 0.75 \mathrm{~g} / \mathrm{dl}, 3.55 \pm 1.50 \mathrm{~g} / \mathrm{dl}$ and $0.97: 1 \pm 0.66 \mathrm{~g} / \mathrm{dl}$ respectively while group $>30$ were $6.50 \pm 1.27 \mathrm{~g} / \mathrm{dl}, 3.10 \pm 0.72 \mathrm{~g} / \mathrm{dl}$, $3.40 \pm 1.58 \mathrm{~g} / \mathrm{dl}$ and $1.42: 1 \pm 1.47 \mathrm{~g} / \mathrm{dl}$. The $\mathrm{P}$ values obtained on comparison based on the two age groups were 0.501 for total protein, 0.025 for albumin, 0.656 for globulin and 0.042 for albumin/globulin ratio.

The age group $<30$ and $>40$ whose total protein, albumin, globulin and albumin/globulin ratio were $6.32 \pm 1.24$ and $6.31 \pm 2.06 \mathrm{~g} / \mathrm{dl}, 2.74$ \pm 0.75 and $2.87 \pm 0.95 \mathrm{~g} / \mathrm{dl}, 3.55 \pm 1.50$ and $3.44 \pm 2.05 \mathrm{~g} / \mathrm{dl}$ and $0.97: 1$ \pm 0.66 and1.24:1 $\pm 1.34 \mathrm{~g} / \mathrm{dl}$ respectively while the $\mathrm{p}$ values as 0.985 , $0.546,0.817$ and 0.213 as shown in Table 5 .

\section{Discussion}

Our study population consisted of a total of 120 participants (42 in the control group and 78 in the tuberculosis (TB) group). The TB 
group had 46 (59\%) male and 32 (41\%) females while the control group was comprised of healthy individuals matched for age and sex. Those $<30$ years had the highest number of participants for both test and control groups $31(39.74 \%)$ and $26(61.9 \%)$, followed by group $30-$ 40 years $9(21.4 \%)$ and $27(34.6 \%)$ in the control and TB group respectively. This agrees with previous reports from developing countries where about $80 \%$ of TB affected individuals were below 30 years $[27,28]$, as compared with reports from developed countries where majority of affected population were above age 50 years. This variation may be due to reactivation from primary or secondary infections caused by co-infection or inexperience in diagnosis and therapeutics approach by health personnel or lack of laboratory facilities as noted by [29].

\begin{tabular}{|c|c|c|c|}
\hline Variable & \multicolumn{3}{|c|}{ Mean \pm SD ( g/dl) } \\
\hline Males & Control group & TB group & p value \\
\hline Total protein & $6.64 \pm 0.90$ & $6.36 \pm 1.76$ & 0.374 \\
\hline Albumin & $2.61 \pm 0.65$ & $3.04 \pm 0.76$ & 0.014 \\
\hline Globulin & $3.95 \pm 0.85$ & $3.32 \pm 1.89$ & 0.103 \\
\hline Albumin/globulin Ratio & $0.70: 1 \pm 0.26$ & $1.34: 1 \pm 1.14$ & 0.006 \\
\hline Females & & & \\
\hline Total protein & $6.98 \pm 0.79$ & $5.888 \pm 1.48$ & 0.002 \\
\hline Albumin & $2.98 \pm 0.58$ & $2.822 \pm 0.99$ & 0.48 \\
\hline Globulin & $3.99 \pm 0.88$ & $3.066 \pm 1.91$ & 0.028 \\
\hline Albumin/globulin ratio & $0.79: 1 \pm 0.27$ & $1.48: 1 \pm 1.58$ & 0.23 \\
\hline
\end{tabular}

Table 3: Comparison of serum protein of subjects based on sex in the control group with TB group.

\begin{tabular}{|c|c|c|c|}
\hline \multirow{2}{*}{ Variable } & \multicolumn{3}{|c|}{ Mean \pm SD ( g/dl) } \\
\hline & \multicolumn{3}{|c|}{ TB case } \\
\hline & New (not on drugs) & on treatment & P value \\
\hline Total protein & $6.60 \pm 1.37$ & $6.07 \pm 1.71$ & 0.226 \\
\hline Albumin & $3.32 \pm 1.11$ & $2.87 \pm 0.79$ & 0.077 \\
\hline Globulin & $3.28 \pm 1.90$ & $3.20 \pm 1.91$ & 0.892 \\
\hline Albumin/globulin ratio & $1.69: 1 \pm 1.98$ & $1.34: 1 \pm 1.15$ & 0.366 \\
\hline Variable & Phase of treatment \\
\hline & Intensive & Continuation & $p$ value \\
\hline Total protein & $6.20 \pm 1.46$ & $5.97 \pm 1.91$ & 0.591 \\
\hline Albumin & $2.84 \pm 0.99$ & $2.89 \pm 0.59$ & 0.792 \\
\hline Globulin & $3.36 \pm 1.80$ & $3.07 \pm 2.01$ & 0.559 \\
\hline Albumin/globulin ratio & $1.25: 1 \pm 1.19$ & $1.40: 1 \pm 1.14$ & 0.612 \\
\hline
\end{tabular}

Table 4: Comparison of serum protein of $\mathrm{TB}$ patients based on treatment regimen.
The mean total protein and globulin was significantly lower in the TB patients when compared to the control group; $6.17 \pm 1.66$ and 6.76 $\pm 1.66 \mathrm{~g} / \mathrm{dl}(\mathrm{p}=0.011), 3.22 \pm 1.90$ and $3.97 \pm 0.86 \mathrm{~g} / \mathrm{dl}(\mathrm{p}=0.016)$ respectively, this might have been caused by anorexia, mal-absorption and impaired cell mediated immunity as noted by Narwadiya [30]. The elevated mean value for albumin/globulin ratio was 1.4 for TB patient, when compared with control subject; at value 0.002 was obtained which is significantly low. In contrast, the mean albumin of $2.95 \pm 0.86$ $\mathrm{g} / \mathrm{dl}$ in TB case was higher than in control group which was $2.75 \pm 0.65$ $\mathrm{g} / \mathrm{dl}$ with $\mathrm{p}$ value 0.149 . No significant difference was observed at $\mathrm{p}>$ 0.05. This is in line with the work of Damburame et al. whose work showed a decrease in total protein among people with TB.

\begin{tabular}{|c|l|l|l|}
\hline \multirow{2}{*}{ Variable } & \multicolumn{3}{|c|}{ Mean \pm SD ( g/dl) } \\
\hline & \multicolumn{3}{|c|}{ Age category } \\
\cline { 2 - 4 } & $<30$ & $>30$ & $p$ value \\
\hline Total protein & $6.32 \pm 1.24$ & $6.50 \pm 1.27$ & 0.501 \\
\hline Albumin & $2.74 \pm 0.75$ & $3.10 \pm 0.72$ & 0.025 \\
\hline Globulin & $3.55 \pm 1.50$ & $3.40 \pm 1.58$ & 0.656 \\
\hline Albumin/globulin ratio & $0.97: 1 \pm 0.66$ & $1.42: 1 \pm 1.47$ & 0.042 \\
\hline
\end{tabular}

Table 5: Comparison of serum protein of TB patients based on age group $<30$ and $>30$.

The mean serum protein of males in the control group were comparable with the TB group, serum albumin and albumin/globulin ratio values were significantly low $2.61 \pm 0.65 \mathrm{~g} / \mathrm{dl}$ for control group $3.04 \pm 0.76 \mathrm{~g} / \mathrm{dl}$ for TB group $\mathrm{p}$ value of 0.014 and $0.70 \pm 0.26$ versus $1.34 \pm 1.14$ having $\mathrm{p}$ value 0.006 while total serum protein and globulin concentrations were high in the control males, this showed no significant difference. On the other hand, mean total serum protein and globulin of females both TB casesandin control were significantly low with $\mathrm{p}$ values $0.002,0.028$ while albumin/globulin ratio was significantly higher 0.023 respectively but that of albumin had $p$ value of 0.480 which was not significantly different. Our work suggests that females with TB show decrease in total protein, albumin and globulin which may be a reflection of their immune system (CD4+ T lymphocyte). Conversely, increased albumin/globulin ratio was possibly due to the role of albumin as an antioxidant to prevent tissue damage and wasting disease in TB individuals [31].

The result obtained from TB patients who were HIV seropositive for antibody with subjects not seropositive had raised globulin value and albumin/globulin ratio while total protein and albumin was low with no significant difference. Serum total protein, albumin, globulin and albumin/globulin ratio had $p$ value $0.89,0.216,0.666$ and 0.78 respectively indicating no significant difference. This increase does not agree with Narwadiya et al., who observed a decrease in serum proteins of $\mathrm{TB}$ and HIV seropositive subjects when compared to control subjects. The decrease in total protein and albumin may be as a result of low immunity and malnutrition. Similarly serum proteins of newly diagnosed TB patients were higher than those on treatment and total protein and globulin of those on intensive care was elevated more than those on continuation phase of treatment. A reverse lower level occurred in serum albumin and albumin/globulin ratio in which both were not statistically significant. The elevation in total protein and globulin could be due to good response to treatment. This agrees with the work of Zia et al., in India where he observed increase total protein 
and globulin in individuals on intensive phase and increased albumin/ globulin ratio in those on continuation phase of treatment [32].

From the results obtained, it is evident that total protein, albumin and albumin/globulin ratio concentration are higher in age group $>30$ years as compared to age category $<30$ years where albumin and albumin/globulin ratio was significantly increase ( $p$ values 0.025 and 0.042 ) whereas total protein of age group $<30$ years had no significant difference while globulin concentration were lower when compared to age group $<30$ years which showed no significant difference. The variation may be due to socioeconomic status of the various aged groups.

Albumin concentration and albumin/globulin ratio was lower at age $<30$ years when compared to age $>40$ whereas total protein and globulin mean value are higher on comparison with age $>40$ years. All had $\mathrm{p}$ values that showed no significant difference. Albumin/globulin ratio level is usually affected in tuberculosis disease this might be due to association of immunoglobulin and cellular immunity in the process.

\section{Conclusion}

Our findings show that albumin/globulin ratio, total protein and globulin had significant difference in TB patients compared to the control group. Males with TB had a significant high serum albumin and albumin globulin ratio compared with those in the control group also female with TB cases had significant low serum total protein and globulin but albumin/globulin ratio was significantly high.

This study shows serum protein of newly diagnosed patients was higher than those on treatment. Conversely, there was increase in serum total protein and globulin of individuals on intensive phase treatment for TB. It was observed that aged group $>30$ years had significant high albumin, albumin/globulin ratio though total protein was elevated in relation to aged $<30$ years.

For effective treatment of individuals with tuberculosis in addition to the use of appropriate anti-tubercular drugs, patients must adhere to treatment and employ frantic effort in the control of associated diseases (co-infection) such as HIV. Since nutritional status influences cellular immunity of the body system, the public should be enlightened on the need to pay close attention on dietary intake that are necessary for maintaining and improving the immune system. Physicians should also be guided on the use of drugs which may serve for boasting the protein level, since proteins are involved in transportation of drugs and building of immune system.

\section{Limitations}

Additional work should be done on a larger population of both HIV and $\mathrm{TB}$ patients over a longer period on different drug regimen.

\section{References}

1. Kumar, Vinay, Abbas Abdul, Fausto, Nelson, et al. (2007) Robbins \& Cotran Pathologic Basis of Disease (8th ed.) Saunders Elsie 516-552.

2. Ochei J, Kolhatkar A (2007) Medical Laboratory Science: Theory and Practice New Delhi. Tata McGraw-Hill: 157-159.

3. Kontantinos A (2010) Testing for tuberculosis. Australian prescriber 33 12-18.

4. Cole EC, Cook CE (1998) Characterization of infectious aerosols in health care facilities: an aid to effective engineering controls and preventive strategies. Am J Infect Control 26: 453-464.
5. Nicas M, Nazaroff WW, Hubbard A (2005) Toward understanding the risk of secondary airborne infection: emission of respirable pathogens. J Occup Environ Hyg 2: 143-154.

6. Ahmed N, Hasnain SE (2011) Molecular epidemiology of tuberculosis in India: moving forward with a systems biology approach. Tuberculosis (Edinb) 91: 407-413.

7. Nigerian tuberculosis Sheet (2010) United States Embassy in Nigeria.

8. Chong T Wong, Nilmani Shah (1989) Serum Immunoglobulin and acute phase protein concentrations in pulmonary tuberculosis patients in Singapore. Tropical and Geographical medicine 41: 218-221.

9. Carl AB, Edward R.A, David EB (2008) Plasma Proteins. Tietz fundamental of clinical chemistry (7th W.B Saunders Philadelphia): 294-297.

10. Centers for Disease Control (2011) Fact Sheets: The Difference between Latent TB Infection and Active TB Disease.

11. Skolnik, Richard (2011) Global health 101 (2nd ed.). Burlington, MA: Jones \& Bartlett Learning: 253.

12. World Health Organization (2011) "The sixteenth global report on tuberculosis".

13. Beyers N, Gie R, Shaaf HS. (1997) A prospective evaluation of children under age of 15 years living in the same household as adults with recently diagnosed pulmonary tuberculosis international Journal tuberculosis. Lung Dis 1: 38-43.

14. World Health Organization (2009) "Epidemiology" Global tuberculosis and Control; epidemiology, strategy, financing: 6-33.

15. Tuberculosis in Nigeria (Web) (2006)

16. Raviglone MC, Nunn P (1997) Epidemiology of tuberculosis. AIDS and respiratory Medicine: $117-141$.

17. World Health Organization (2006) Global Tuberculosis Control Report.

18. Davies PD, Yew WW, Ganguly D, Davidow AL, Reichman LB, et al. (2006) Smoking and tuberculosis: the epidemiological association and immunopathogenesis. Trans R Soc Trop Med Hyg 100: 291-298.

19. Kumar D, Watson JM, Charlett A, Nicholas S, Darbyshire JH (1997) Tuberculosis in England and Wales in 1993: results of a national survey. Public Health Laboratory Service/British Thoracic Society/Department of Health Collaborative Group. Thorax 52: 1060-1067.

20. Strachan DP, Powell KJ, Thaker A, Millard FJ, Maxwell JD (1995) Vegetarian diet as a risk factor for tuberculosis in immigrant south London Asians. Thorax 50: 175-180.

21. Nnoaham KE, Clarke A (2008) Low serum vitamin D levels and tuberculosis: a systematic review and meta-analysis. Int J Epidemiol 37: 113-119.

22. Larouzé B, Sánchez A, Diuana V (2008) Tuberculosis behind bars in developing countries: a hidden shame to public health. Trans R Soc Trop Med Hyg 102: 841-842.

23. Ferdinand Rose (1857) On the compounds of albumin with metal oxides, PoggendorfsAnnalen der Physik und Chemie 104: 132-142.

24. Diamond D1, Lau KT, Brady S, Cleary J (2008) Integration of analytical measurements and wireless communications--current issues and future strategies. Talanta 75: 606-612.

25. Ali-Gombe A (1991) Factors affecting sputum conversion in patients with active pulmonary tuberculosis using the modified short-course therapy and the conventional short-course therapy.

26. Idigbe EO, Sofola TO, John EKO, Okoye R, Onugbogu C, et al. (1995) Trend of pulmonary tuberculosis in Lagos, Nigeria. Biomed.Lett., 51: 99-109.

27. Zevallos M, Justman JE (2003) Tuberculosis in the elderly. Clin Geriatr Med 19: 121-138.

28. Narwadiya SC, Dhumne UL, Sahare KN, Tumane PM, Meshram VG, et. al (2012) Serum Protein Level Changes in Dots Administered Patients of Nagpur District: A Case Study. Department of Microbiology and Biochemistry, R. T M Nagpur University, Nagpur. 
Citation: Shingdang J, Bot Y, Ojo O, Edeh O, Ekwempu Al, et al. (2016) Serum Albumin/Globulin ratio in Tuberculosis and HIV Patients any Relationship?. Mycobact Dis 6: 199. doi:10.4172/2161-1068.1000199

Page 6 of 6

29. Akiibinu MO, Arinola OG, Ogunlewe JO, and Onih EA (2007) NonEnzymatic Antioxidants and Nutritional Profiles in Newly Lynch's Medical LaboratoryTechnology, Stanlay S.Raphael (3rd ed.) 228.

30. Zia H Khan, Shankar S Warke (2012) Department of Biochemistry, ShriShivaji College, Akola (M.S.) Department of Pathology, T.N.Medical College and B.Y.L. Nair Ch. Hospital.

31. Egah DZ, Banwat EB, Alanana JA, Badung BP, Damen GJ, et al. (2004) Tuberculosis in Jos Nigeria: A 9-year Review of laboratory Report at the
Jos University Teaching Hospital. Nigerian Medical practitioner 46: 33-35.

32. Chacón-Salinas R, Serafín-López J, Ramos-Payán R, Méndez-Aragón P, Hernández-Pando R, et al. (2005) Differential pattern of cytokine expression by macrophages infected in vitro with different Mycobacterium tuberculosis genotypes. Clin Exp Immunol 140: 443-449. 